\title{
Paralytic shellfish toxin content is related to genomic sxtA4 copy number in Alexandrium minutum strains
}

\author{
Anke Stüken ${ }^{*}$, Pilar Riobó2 ${ }^{2}$ José Franco ${ }^{2}$, Kjetill S. Jakobsen ${ }^{3}$, Laure Guillou ${ }^{4,5}$ and \\ Rosa I. Figueroa ${ }^{6,7}$
}

\begin{abstract}
${ }^{1}$ Department of Biosciences, University of Oslo, Oslo, Norway, ${ }^{2}$ U.A. Microalgas Nocivas (Consejo Superior de Investigaciones Científicas - Instituto Español de Oceanografía), Instituto de Investigaciones Marinas, Vigo, Spain, ${ }^{3}$ Centre for Ecological and Evolutionary Synthesis, Department of Biosciences, University of Oslo, Oslo, Norway, ${ }^{4}$ Laboratoire Adaptation et Diversité en Milieu Marin, CNRS, UMR 7144, Roscoff, France, ${ }^{5}$ Sorbonne Universités - Université Pierre et Marie Curie, UMR 7144, Roscoff, France, ${ }^{6}$ Aquatic Ecology, Lund University, Lund, Sweden, ${ }^{7}$ U.A. Microalgas Nocivas (Consejo Superior de Investigaciones Cientificas - Instituto Español de Oceanografía), Instituto Español de Oceanografía, Vigo, Spain
\end{abstract}

OPEN ACCESS

Edited by:

Senjie Lin,

University of Connecticut, USA

Reviewed by:

Deana Erdner,

Uiversity of Texas at Austin, USA Paulo João Vieira Vale, Instituto Português do Mar e da Atmosfera, Portugal

*Correspondence: Anke Stüken,

Department of Biosciences, University of Os/o, P.O. Box 1066, Blindern,

0316 Oslo, Norway anke.stuken@web.de

Specialty section: This article was submitted to

Aquatic Microbiology, a section of the journal

Frontiers in Microbiology

Received: 03 September 2014 Accepted: 17 April 2015

Published: 01 May 2015

Citation:

Stüken A, Riobó P, Franco J,

Jakobsen KS, Guillou L and Figueroa RI (2015) Paralytic shellfish toxin content is related to genomic sxtA4 copy number in Alexandrium minutum strains.

Front. Microbiol. 6:404. doi: 10.3389/fmicb.2015.00404
Dinoflagellates are microscopic aquatic eukaryotes with huge genomes and an unusual cell regulation. For example, most genes are present in numerous copies and all copies seem to be obligatorily transcribed. The consequence of the gene copy number (CPN) for final protein synthesis is, however, not clear. One such gene is $s x t A$, the starting gene of paralytic shellfish toxin (PST) synthesis. PSTs are small neurotoxic compounds that can accumulate in the food chain and cause serious poisoning incidences when ingested. They are produced by dinoflagellates of the genera Alexandrium, Gymnodium, and Pyrodinium. Here we investigated if the genomic CPN of $s x t A 4$ is related to PST content in Alexandrium minutum cells. SxtA4 is the 4th domain of the sxtA gene and its presence is essential for PST synthesis in dinoflagellates. We used PST and genome size measurements as well as quantitative PCR to analyze sxtA4 CPN and toxin content in $15 \mathrm{~A}$. minutum strains. Our results show a strong positive correlation between the sxtA4 CPN and the total amount of PST produced in actively growing $A$. minutum cells. This correlation was independent of the toxin profile produced, as long as the strain contained the genomic domains sxtA1 and sxtA4.

Keywords: Dinoflagellate, Alexandrium, saxitoxin (STX), paralytic shellfish toxin (PST), sxtA, gene dosage, copy number variation, genome size

\section{Introduction}

"From the beginning, the problem of mussel poisoning appeared to be complex," Dr. R. Stohler, 1937 (Sommer et al., 1937). Over 60 years later, despite many great advances in research on origin and diversity of mussel toxins, the phenomenon of paralytic shellfish poisoning (PSP) is still not fully explained. Stohler was co-author on a series of papers that summarized the knowledge on PSP at the time. Among the main breakthroughs was the identification of the dinoflagellate Alexandrium catenella (Whedon and Kofoid) Balech as the plankton species responsible for PSP outbreaks along the Pacific coast of North America. They showed that the mussels became toxic when they fed on A. catenella and gradually lost their toxicity after the mussels stopped feeding 
on it. Sommer et al. (1937) also demonstrated that the paralytic shellfish toxins (PSTs) were present in plankton samples containing A. catenella, that the PST content in the dinoflagellates varied and that it was likely to consist of more than one active substance.

Paralytic shellfish toxins are a group of small neurotoxic alkaloids that are among the most potent natural toxins known. To date, 57 isoforms of saxitoxin, the parent compound of PSTs, have been described (reviewed in Wiese et al., 2010). More PST-producing plankton species have also been identified. These include additional Alexandrium species, and the two dinoflagellates Gymnodinium catenatum Graham and Pyrodinium bahamense Plate, but also several species of freshwater cyanobacteria.

On a worldwide basis, Alexandrium species are the most abundant and widespread (Anderson et al., 2012) and much research has focused on identifying factors that influence PST synthesis in this genus (recent review: Anderson et al., 2012). About one third of the 31 taxonomically accepted Alexandrium species today have been reported to produce PSTs (Anderson et al., 2012; Guiry and Guiry, 2013). The mix of PST isoforms produced, i.e., the PST profile, appears to be fixed in each strain and is thought to be inherited in Mendelian fashion (Sako et al., 1992) but can vary between strains of the same species. The total amount of PSTs and the relative proportions of the PST isoforms produced, however, can vary in each strain in response to a range of biotic and abiotic factors. These include for example nutrient limitations (Boczar et al., 1988; Anderson et al., 1990; John and Flynn, 2000), intracellular arginine concentration (Anderson et al., 1990; John and Flynn, 2000), temperature (Anderson et al., 1990), and grazer presence (Bergkvist et al., 2008). In addition, strains that do not produce any detectable amounts of PSTs have also been reported to occur within otherwise PST-producing Alexandrium species.

Despite these advances, it is still not known how PST synthesis is regulated at a cellular level in dinoflagellates. This gap of knowledge is most likely due to the unusual genome organization of dinoflagellates. For one dinoflagellate genomes are huge. Haploid genome size measurements range from 1.5 to $>225 \mathrm{pg}$ cell per cell (Veldhuis et al., 1997; LaJeunesse et al., 2005) and thus correspond to 0.5 to $>70$ times the human haploid genome. The biggest part of dinoflagellate genomes is made up of simple and complex repeats (Allen et al., 1975; Davies et al., 1988; McEwan et al., 2008; Jaeckisch et al., 2011) and only about $0.2-1.8 \%$ of sequence code for protein coding genes (McEwan et al., 2008; Hou and Lin, 2009; Jaeckisch et al., 2011). These genes frequently occur in multiple copies and are often arranged in tandem arrays (Le et al., 1997; Li and Hastings, 1998; Bachvaroff and Place, 2008; Shoguchi et al., 2013), but single-copy-genes may also exist (Bachvaroff and Place, 2008). The different copies of multi-copy genes are often not identical (Lee et al., 1993; Machabée et al., 1994), and it appears as if all gene copies are constantly expressed (Machabée et al., 1994). Further, recent studies using whole transcriptome sequencing technology (Moustafa et al., 2010; Yang et al., 2010) or microarray analyses (Yang et al., 2011) suggest that only $0.35-27 \%$ of dinoflagellate genes are transcriptionally regulated.
The copy numbers (CPNs) of different genes within one species vary widely. For example, the dinoflagellate Lingulodinium polyedra (Stein) Dodge has been reported to contain $\sim 30$ copies of a protein kinase gene (Salois and Morse, 1997), 146 copies of the luciferase gene (Liu and Hastings, 2005), 1,000 copies of the Luciferin-binding Protein genes (Lee et al., 1993) and $\sim 5,000$ copies of the mitotic cyclin gene (Bertomeu and Morse, 2004). The importance of these high gene CPNs for the cellular biology of dinoflagellates is not clear. However, it has been suggested that they may be related to the amount of protein that can be synthesized by a dinoflagellate cell (Lee et al., 1993, 2014; Moustafa et al., 2010).

Recently, two research groups have identified transcripts and transcript fragments that are putatively involved in PST synthesis in dinoflagellates (Stüken et al., 2011; Hackett et al., 2013; Orr et al., 2013). Both groups have independently identified transcripts that are related to sxtA (Stüken et al., 2011; Hackett et al., 2013) the putative starting gene of PST synthesis in cyanobacteria (Kellmann et al., 2008). The cyanobacterial sxtA gene contains four catalytic domains, sxtA1 to sxtA4 (Kellmann et al., 2008) and dinoflagellate transcripts containing either sxtA1-A3 or all four catalytic domains have been characterized in detail (Stüken et al., 2011). The organization of the four domains within the dinoflagellate genome, however, is unresolved: so far, only genomic fragments of sxtA1 and sxtA4 could be amplified, not the entire gene (Stüken et al., 2011). However, evidence is accumulating that PST-producing dinoflagellates contain genomic copies of $s x t A 1$ and $s x t A 4$, whereas one or both of these domains are often not detected in dinoflagellates that do not produce PSTs (Murray et al., 2011b, 2012; Stüken et al., 2011; Orr et al., 2013; Suikkanen et al., 2013). In addition it has been shown that at least sxtA4 occurs in multiple, non-identical genomic copies (Stüken et al., 2011; Wiese et al., 2014). These different copies are most likely constitutivly transcribed: divergent sxtA1 and sxtA4 transcript families have been detected in Alexandrium transcriptomes (Stüken et al., 2011). Further, specific sxtA4 transcript analyses of A. catenella strains did not reveal any changes in transcript levels throughout the growth cycle, despite significant changes in PST production rates (Wiese et al., 2014).

The aim of this study was to investigate if there is a relationship between the genomic CPN of sxtA4 and PST content in dinoflagellate cells. We focused on A. minutum, a globally distributed Alexandrium species that contains PST-producing and non-producing strains. We measured genome size and PST content and estimated the genomic sxtA4 CPN in all strains using quantitative PCR methods.

\section{Materials and Methods}

\section{Strains and Culture Conditions}

The A. minutum strains studied are listed in Table 1. All strains were grown in L1 medium (Guillard and Hargraves, 1993) without added silica, at $30 \mathrm{PSU}$ salinity, $16^{\circ} \mathrm{C}$, a $12: 12 \mathrm{~h}$ light-dark photoperiod and a photon irradiance of $90-100 \mu \mathrm{mol}$ photons $\mathrm{m}^{2} \mathrm{~s}^{-1}$. Strains were xenic. 
TABLE 1 | Overview over the Alexandrium minutum strains used in this study, their genome size, genomic sxtA4 CPNs, and average total PST content.

\begin{tabular}{|c|c|c|c|c|c|c|c|c|c|}
\hline \multirow{2}{*}{$\begin{array}{l}\text { Strain } \\
\text { (Synonym) }\end{array}$} & \multicolumn{2}{|l|}{ Isolation } & \multicolumn{2}{|c|}{ Genome } & \multicolumn{2}{|c|}{ sxtA4 } & \multicolumn{2}{|c|}{ Total PST } & \multirow{2}{*}{$\begin{array}{c}\text { Toxin group } \\
*\end{array}$} \\
\hline & Location & Year & Size [pg] & SD & CPN cell ${ }^{-1}$ & SD & fmol cell-1 & SD & \\
\hline AL1V (CCMP113) & Ria de Vigo, Spain & 1987 & 22.5 & 3.8 & 4.3 & 1.9 & 0.442 & 0.000 & 1 \\
\hline VGO722 & Cambrils, Catalonia, Spain & 2003 & 23.3 & 1.0 & 2.2 & 0.5 & 2.269 & 0.292 & 1 \\
\hline AMP13 & Palma de Mallorca, Spain & 1995 & 24.4 & 2.3 & 2.3 & 0.5 & 6.200 & 4.111 & 1 \\
\hline AL10C & Estartit, Catalonia, Spain & 2002 & 24.5 & 2.2 & 2.4 & 0.9 & 0.115 & 0.026 & 1 \\
\hline VGO942 & Adriatic Sea, Italy & 2008 & 24.9 & 1.5 & 1.5 & 1.0 & 0.681 & 0.731 & 1 \\
\hline $\mathrm{AL} 4 \mathrm{~V}$ & Ria de Vigo, Spain & 2000 & 25.2 & 2.6 & 7.0 & 5.4 & 2.358 & 0.360 & 1 \\
\hline Min3 & Arenys, Catalonia, Spain & 2002 & 25.2 & 2.2 & 2.0 & 1.1 & 0.650 & 0.439 & 1 \\
\hline VGO577 & Girona, Catalonia, Spain & 2002 & 25.7 & 3.2 & 6.4 & 0.5 & 6.574 & 4.336 & 1 \\
\hline AMP4 & Palma de Mallorca, Spain & 1995 & 26.2 & 3.0 & 4.0 & 2.2 & 8.446 & 2.762 & 1 \\
\hline VG0874 & Boughrara, Tunesia & 2006 & 29.0 & 3.4 & 2.8 & 0.2 & 0.531 & 0.181 & 1 \\
\hline RCC3227 & Rance river, Brittany, France & 2011 & 25.4 & 1.7 & 10.8 & 3.3 & 3.303 & 4.689 & 2 \\
\hline RCC3337 & Penzé river, Brittany, France & 2011 & 26.3 & 2.4 & 5.8 & 2.2 & 1.850 & 1.108 & 2 \\
\hline VGO650 & Brittany, France & 2003 & 26.5 & 1.7 & 6.3 & 0.7 & 15.915 & 3.343 & 2 \\
\hline VG0651 & Brittany, France & 2003 & 26.9 & 3.5 & 7.7 & 1.2 & 17.773 & 8.888 & 2 \\
\hline VGO663 & Sardina, Italy & 2003 & 29.6 & 2.6 & N.D. & & N.D. & & 3 \\
\hline
\end{tabular}

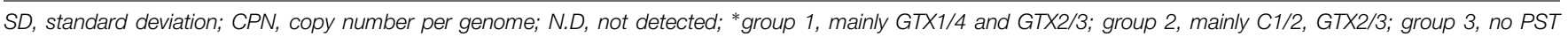
detected.

\section{Genome Size Measurements}

Exponentially growing cultures $\left(6,000-10,000\right.$ cells $\left.\mathrm{mL}^{-1}\right)$ were incubated $48 \mathrm{~h}$ in darkness to induce synchronization of cell division in Alexandrium (Taroncher-Oldenburg et al., 1997; Figueroa et al., 2010). Fifty milliliter of culture were filtered through a $5.0 \mu \mathrm{m}$ isopore membrane filter (Millipore, Ireland), fixed with $1 \%$ paraformaldehyde for $10 \mathrm{~min}$, and washed in PBS ( $\mathrm{pH}$ 7, Sigma-Aldrich, St. Louis, MO, USA; $1200 \mathrm{~g} \times 10 \mathrm{~min}$ ). The pellet was re-suspended in $2 \mathrm{~mL}$ of cold methanol and stored for at least $12 \mathrm{~h}$ at $4^{\circ} \mathrm{C}$ to allow chlorophyll extraction. The cells were then washed twice in PBS and the pellet was resuspended in a staining solution (PBS, $0.1 \mathrm{mg}$ propidium iodide $\mathrm{mL}^{-1}$ and $2 \mu \mathrm{g}$ RNaseA $\mathrm{mL}^{-1}$ ) for at least $2 \mathrm{~h}$ before analysis. A Beckman FC500 bench machine with a laser emitting at $488 \mathrm{~nm}$ was used. Four replicate samples were run at low speed $\left(\sim 18 \mu \mathrm{L} \mathrm{min}^{-1}\right)$ and data were acquired in linear and log modes until at least 1000 events had been recorded. As DNA standard, $10 \mu \mathrm{l}$ of a triploid trout solution (7.8 pg nucleus ${ }^{-1}$, Biosure, USA) was added to each sample. Fluorescence emission of propidium iodide was detected at $620 \mathrm{~nm}$. The software FlowJo 7.6 (Tree Star, Inc., USA) was used to compute peak numbers, coefficients of variation (CVs), and peak ratios for the DNA fluorescence distributions in a population. Runs with CVs above 10 were discarded from analyses.

\section{PST Measurements}

The cultures grown for toxin analyses are listed in Table 1. They were grown in batch mode in $500 \mathrm{~mL}$ Erlenmeyer flasks containing $250 \mathrm{~mL}$ of L1 medium (see Strains and Culture Conditions for details). The cultures were initiated at a density of 500 cells $\mathrm{mL}^{-1}$ provided by the inoculation of each flask with acclimated exponentially growing cells. For growth monitoring $5 \mathrm{~mL}$ samples were collected every 3 days, fixed with Lugol's solution and cell counts in Sedgewick-Rafter slides. For toxin analyses, three $50 \mathrm{ml}$ aliquots were harvested in actively growing cultures using two different inocula. Cultures were filtered using $1.4 \mu \mathrm{m} \mathrm{GF} / \mathrm{C}$ glass fiber filters $(25 \mathrm{~mm} \theta)$. Toxins in cells were extracted with $1000-2500 \mu \mathrm{L}$ acetic acid $0.05 \mathrm{M}$ depending on cell concentration.

The PSP toxins were separated using the method proposed by Rourke et al. (2008) Standard solutions of GTX4,1, dcGTX2,3, GTX2,3, STX, neoSTX, and dcSTX were purchased from the Institute for Marine Bioscience, National Research Council, Certified Reference Material Program (NRC-CRM), Halifax, NS, Canada. Toxin concentrations were determined by comparing the peak area for each toxin with that of the standard.

\section{DNA Isolation and Quantification}

Genomic DNA was isolated using the following Cetyl Trimethyl Ammonium Bromide (CTAB) protocol: Alexandrium cultures were harvested through centrifugation and pellets were stored at $-80^{\circ} \mathrm{C}$. To isolate DNA, $700 \mu \mathrm{l} \mathrm{CTAB}$ buffer containing $4 \% 0(\mathrm{v} / \mathrm{v})$ 2-Mercapthoethanol and $0.1 \mathrm{mg} \mathrm{ml}^{-1}$ Proteinase $\mathrm{K}$ was added to each thawed pellet. Samples were vortexed, then incubated for $1 \mathrm{~h}$ at $65^{\circ} \mathrm{C}$ during which they were inverted every $10 \mathrm{~min}$. Samples were let to cool, $700 \mu \mathrm{l}$ chloroform: isoamyl alcohol (24:1) was added, samples were mixed by inversion and then shaken horizontally for $20 \mathrm{~min}$. Afterward, samples were centrifuged at $4^{\circ} \mathrm{C}$, $15,700 \times g$ for $20 \mathrm{~min}$, the upper aqueous phase was transferred to a fresh tube and the chloroform: isoamyl alcohol step was repeated on the transferred extract. Then $1 \mu \mathrm{l}$ RNAse A $(10 \mathrm{mg}$ $\mathrm{ml}^{-1}$ ) was added and samples were incubated for $30 \mathrm{~min}$ at $37^{\circ} \mathrm{C}$. Then 1.5 volumes $96 \% \mathrm{EtOH}$ and 0.1 volumes sodium acetate $3 \mathrm{M}, 5.2 \mathrm{pH}$ were added, and the samples stored at $-20^{\circ} \mathrm{C}$ over night. The DNA was recovered by centrifugation $\left(20 \mathrm{~min}, 4^{\circ} \mathrm{C}\right.$, $15,700 \times g)$. The supernatant was carefully removed and the DNA washed with $200 \mu \mathrm{l}$ of cold $70 \% \mathrm{EtOH}$ (centrifugation $20 \mathrm{~min}$, $4^{\circ} \mathrm{C}, 15,700 \times g$ ). The EtOH was removed and the pellet was air dried, before $25 \mu \mathrm{l} \mathrm{TE}$ buffer was added and the DNA re-dissolved at $65^{\circ} \mathrm{C}$ for $1 \mathrm{~h}$. 
A subsample of the isolated DNA was run on a $1 \%$ agarose gel stained with GelRed ${ }^{\mathrm{TM}}$ (Biotium) and photographed to assess the integrity of the genomic DNA. If the DNA was degraded or contained many short fragments, then paramagnetic beads (Agencourt AMPure XP system, Beckman Coulter Inc.) were used to select for DNA fragments $>500 \mathrm{bp}$. In short, the manufacturers protocol for PCR purification was followed, but fewer beads than suggested were used (volume beads used here $=0.5 \mathrm{x}$ DNA volume). The elution buffer was $25 \mu \mathrm{l}$ TE. Finally, the genomic DNA was quantified with a Qubit ${ }^{\circledR}$ Fluorometer using the dsDNA HS Assay (Invitrogen).

\section{SxtA1 and SxtA4 Sequencing and Cloning}

SxtA1 and sxtA4 PCRs were run according to Stüken et al. (2011) using primers sxt001/sxt002 and sxt007/sxt008 (Table 2), respectively. Selected products were Sanger sequenced using the same primers. SxtA4 products from strains RCC3227 and RCC3337 were cloned and sequenced using the procedure described in Stüken et al. (2011).

\section{Quantitative PCR}

All quantitative PCRs (qPCRs) were performed on a Roche LightCycler $^{\circledR} 480$ system in white 96-well-plates using LightCycler $^{\circledR} 480$ SYBR Green I Master chemistry (Roche Diagnostics AG, Penzberg, Germany). The sample DNA was freshly diluted with PCR-grade water prior to each experiment. All reactions were run in duplicate or triplicate. Two different qPCRs were run on each DNA, a 5.8S- and a sxtA4-targeted qPCR.

The 5.8S qPCR was based on the qPCR assay developed by Galluzzi et al. (2004) but run with a slightly modified protocol as described in Orr et al. (2013). In short, each reaction contained $0.5 \mathrm{x}$ SYBR Green I master mix, $150 \mathrm{nM}$ of each primer (5.8Sb5' ed and 5.8S-b3', Table 2) and between 2, 4, or 8 ng genomic DNA. The cycling protocol was: hot start, one cycle of $95^{\circ} \mathrm{C}$ for $10 \mathrm{~min}$; amplification, 45 cycles of $95^{\circ} \mathrm{C}$ for $15 \mathrm{~s}$ and $60^{\circ} \mathrm{C}$ for $45 \mathrm{~s}$, with single acquisition; followed by the melt curve program, one cycle of $95^{\circ} \mathrm{C}$ for $5 \mathrm{~s}$ and $65^{\circ} \mathrm{C}$ for $1 \mathrm{~min}$, with up to $97^{\circ} \mathrm{C}$ continuous measurements; and finally, cooling, one cycle of $40^{\circ} \mathrm{C}$ for $10 \mathrm{~s}$.

The $s x t A$ qPCRs were run according to the SYBR Green protocol developed by Stüken et al. (2013). In short, each reaction contained a final concentration of $0.5 x$ SYBR Green I master mix, $125 \mathrm{nM}$ of each primer (sxt072 and sxt073, Table 2), and a known quantity of genomic DNA (1, 2, or $4 \mathrm{ng}$ ). The cycling protocol was: hot start, one cycle $95^{\circ} \mathrm{C}$ for $10 \mathrm{~min}$; amplification, 45 cycles $15 \mathrm{~s}$ at $95^{\circ} \mathrm{C}, 15 \mathrm{~s}$ at $64^{\circ} \mathrm{C}$, and $30 \mathrm{~s}$ at $72^{\circ} \mathrm{C}$; followed by the same melt curve and cooling program as for the 5.8S qPCR (see above). A purified sxtA4 PCR product generated from genomic DNA of strain CCMP113 with primers sxt007 and sxt008 (Table 2) according to Stüken et al. (2011) was run on each sxtA4 qPCR plate as a standard and contained $\sim 800,000$ sxtA4 copies.

Quantitative PCR efficiency calculations were based on the kinetics of individual PCR reactions using the algorithm implemented in the Real-time PCR Miner (Zhao and Russell, 2005), available online at: http://www.miner.ewindup.info/. To convert the raw data from the Roche LightCycler ${ }^{\circledR} 480$ system into the right format, the program LC480Conversion.exe originally written for the LinRegPCR program (Ruijter et al., 2009) was used. It is available at: http://www.hartfaalcentrum.nl/.

\section{SxtA4 Copy Number Determination}

First, the mean efficiency $\left(\right.$ mean $_{\mathrm{eff}}$ ) of all positive $s x t A 4 \mathrm{qPCR}$ reactions and the corresponding slope $(s)$ were calculated: $s=\frac{-1}{\log _{10}\left(\text { mean }_{\mathrm{eff}}+1\right)}$. Then to standardize between the qPCR runs, the intercept $\left(i_{\text {plate }}\right)$ for each plate was calculated: $i_{\text {plate }}=\left(\frac{\mathrm{CP} 1+\mathrm{CP} 2}{2}\right)-s \times \log _{10} \mathrm{STD}$. CP1 and $\mathrm{CP} 2$ were the crossing points of the standard (STD) on each plate. The standard contained $\sim 800,000$ sxtA4 copies per reaction, see Section "Quantitative PCR" for details. Next, the sxtA4 CPN in each reaction $\left(\mathrm{CPN}_{\mathrm{R}}\right)$ was calculated: $\mathrm{CPN}_{\mathrm{R}}=10^{\frac{\left(\mathrm{CP}_{\mathrm{R}}-i_{\text {plate }}\right)}{\mathrm{s}}}$, where $\mathrm{CP}_{\mathrm{R}}$ is the crossing point of the individual reaction. Finally, the sxtA4 CPN per genome $\left(\mathrm{CPN}_{\mathrm{G}}\right)$ was estimated by first calculating the $s x t A 4 \mathrm{CPN}$ per ng $\left(\mathrm{CPN}_{\mathrm{ng}}\right): \mathrm{CPN}_{\mathrm{ng}}=\frac{\mathrm{CPN}_{\mathrm{R}}}{\mathrm{DNA}_{\mathrm{in}}}$, where $D N A_{\text {in }}$ is the amount of input DNA in ng, and then per genome: $\mathrm{CPN}_{\mathrm{G}}=\mathrm{CPN}_{\mathrm{ng}} \times \frac{G_{\text {size }}}{1000}$, where $G_{\text {size }}$ is the measured genome size in $\mathrm{pg}$.

\section{Correlation Analyses}

To test for associations between genome size, gene CPN, and total PSTs produced Spearman's rho was calculated using the cor.test function implemented in the $\mathrm{R}$ statistical software (package stats version 2.14.1).

TABLE 2 | Primers used in this study.

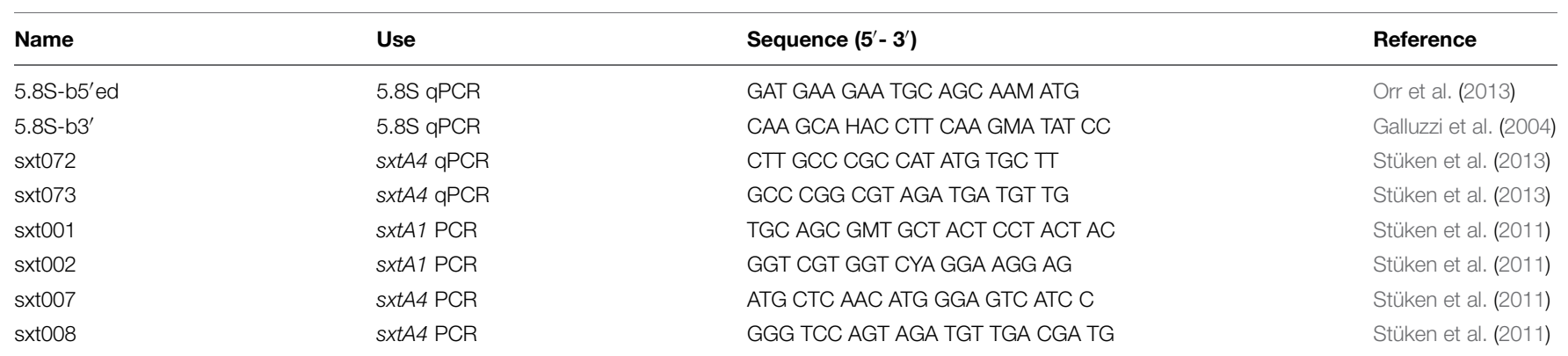




\section{Results}

\section{Genome Size Measurements}

The A. minutum genome sizes are listed in Table $\mathbf{1}$ and ranged from 22.5 to $29.6 \mathrm{pg} \mathrm{cell}^{-1}$, with an average of $25.7 \pm 1.9 \mathrm{pg}$ cell $^{-1}(n=15)$. The genome sizes of toxin group 1 strains (see PST Measurements for toxin profile details) ranged between 22.5 and $29.0 \mathrm{pg}$ and of toxin group 2 strains between 25.4 and $26.9 \mathrm{pg}$. Strain VGO663 had the biggest genome; a strain in which no PST toxins nor sxtA4 copies were detected and the sole member of toxin group 3 .

\section{PST Measurements}

The results of the toxin analyses are listed in Tables 1 and 3. Three groups of PST profiles were observed: (1) GTX1/4 and GTX2/3 (strains isolated from different locations in the Mediterranean Sea and the Atlantic Ocean); (2) C1/2, GTX2/3, and dcGTX2/3 (strains isolated from Brittany, France), and (3) no PST detected (strain VGO663 isolated off Sardinia, Italy).

The total PST content varied considerably between the different strains within each toxin group, and in some cases also between measurements of the same strains. But altogether were the mean and median values higher in toxin group 2 (mean $\pm \mathrm{SD}=9.710 \pm 8.769$; median $=8.364$; $n=12$ ) than in group 1 (mean $\pm \mathrm{SD}=2.997 \pm 3.506$; median $=1.865 ; n=29$ ).

\section{Quantitative PCR and sxtA Gene Copy Numbers Per Genome}

The 5.8S qPCR had an amplification efficiency based on all samples of $0.65 \pm 0.05$ (mean $\pm \mathrm{SD}, n=124$ ). All Alexandrium strains amplified with single, specific meltcurve.

The sxtA qPCR had an amplification efficiency of $0.94 \pm 0.06$ (mean $\pm \mathrm{SD}, n=141$ ) and amplification was observed for all Alexandrium strains tested, apart from A. affine strains CCMP112, A. andersonii CCMP2222, and A. minutum VGO663. The majority of amplified strains showed a specific melt curve with a single peak. The four A. minutum strains isolated from the Channel, Brittany, France (VGO650, VGO651, RCC3337, and RCC3227), however, had a distinct melt curve with a double peak (Figure 1). This double peak was due to three SNP loci in the qPCR amplicon only present in the Brittany strains.

The sxtA4 CPN per genome varied between $1.5 \pm 1.0$ and $10.8 \pm 3.3$ (mean \pm SD; Table 1 ) in all A. minutum strains investigated. The CPNs ranged from $1.5 \pm 1.0$ to $7.0 \pm 5.4$ in toxin group 1 and $5.8 \pm 2.2$ to $10.8 \pm 3.3$ in toxin group 2 (Table 1).

\section{SxtA1 and SxtA4 Amplification and Sequence Diversity}

The PCRs for sxtA1 and sxtA4 amplified single products of the right size for all PST producing strains. No amplification was observed for A. minutum VGO663, as well as the A. affine and A. andersonii strains.

Direct sequencing of the $670 \mathrm{bp}$ long sxtA4 fragment resulted in identical sequences without SNPS for strains AL1V, AL10C, AL4, and Min3. The sequences of strain VGO577 and VGO847 had three and six SNPs over the same length. The SNPs were located outside the region used for $\mathrm{qPCR}$ and also present in the transcriptome of strain AL1V (Stüken et al., 2011). Strains VGO650 and VGO651, had 14 and 16 SNPs, respectively, none of which coincided with SNPs of the AL1V transcriptome. The sxtA4 amplicons from RCC3337 and RCC3227 were cloned and sequenced. These sequences confirmed the SNP positions observed in VGO650 and 651. Three of the SNPs observed in VGO650, VGO651, RCC3337, and RCC3227 were located between qPCR primers sxt072 and sxt073 and resulted in two distinct sequences. None of the SNPs observed in any of the $A$. minutum sequences coincided with SNPs in the A. fundyense CCMP1719 transcriptome (Stüken et al., 2011), which had 12 SNPs over the same length.

Direct sequencing of the sxtA1 amplicons (503 bp) resulted in identical sequences for strains AL1V, AL10C, AL4V, Min3, VGO577, and VGO874, sequences from strains VGO650 and VGO651 were 1 bp different.

Sequences have the GenBank accession numbers KM438016KM438027.

\section{Correlation Analyses}

Only strains for which $s x t A 4$ could be amplified were included in the analyses. The Spearman rank order correlation results indicated significant positive relations between sxtA4 CPN per genome and total toxin content per cell $(\rho=0.470, S=4844$, $p=0.003$, Figure 2A), and between total toxin content per cell and genome size ( $\rho=0.355, S=5896, p=0.029$, Figure 2B). No significant relation was detected between genome size and sxtA4 CPN per cell ( $\rho=0.473, S=240, p=0.088$, Figure 2C).

\section{Discussion}

\section{Relation between sxtA Gene Copy Number, PST Content and Genome Size}

The results of this study support our previous idea that strains with low levels of PST have fewer copies of the sxt genes compared to those with higher toxin levels (Stüken et al., 2011). Specifically, the results show a strong positive correlation between the genomic CPN of sxtA4 domains and the total cellular content of PST in actively growing $A$. minutum cultures (Figure 2). It has been shown that the toxin content and profile of the same A. minutum culture throughout the growth curve are generally stable even under different nutrient conditions. Exceptions are limiting conditions, especially the combination of $\mathrm{P}$ and $\mathrm{N}$ limitations, where toxin content may increase drastically (Flynn et al., 1994). By taking several PST measurements from each strain during active growth and pooling the results, we aimed at capturing the typical variation of toxin production in each strain under standard growth conditions. Thus, our results indicate that strains with a higher genomic sxtA $4 \mathrm{CPN}$ have on average a higher PST content.

Interestingly, the genomic sxtA4 CPN reported for $A$. catenella strains previously is considerably higher than found for the $A$. minutum strains here. All A. minutum strains were estimated to have fewer than 15 copies per genome (Table 1), while 100-280 genomic copies have been reported for A. catenella (Murray 
TABLE 3 | PST measurements in fmol cell-1.

\begin{tabular}{|c|c|c|c|c|c|c|c|c|c|c|c|}
\hline Strain & Sample & Cells $\mathrm{ml}^{-1}$ & C1 & $\mathrm{C} 2$ & GTX4 & GTX1 & dcGTX3 & dcGTX2 & GTX3 & GTX2 & Total PST \\
\hline Al1V & 1 & & & & 0.299 & 0.143 & & & & & 0.442 \\
\hline \multirow[t]{3}{*}{ VGO722 } & 1 & 42660 & & & 1.776 & 0.682 & & & 0.059 & 0.029 & 2.546 \\
\hline & 2 & 17973 & & & 2.006 & 0.208 & & & 0.082 & & 2.296 \\
\hline & 3 & 34800 & & & 1.802 & 0.128 & & & 0.023 & 0.011 & 1.965 \\
\hline \multirow[t]{3}{*}{ AMP13 } & 1 & 27930 & & & 8.038 & 1.735 & & & 0.110 & 0.034 & 9.917 \\
\hline & 2 & 23573 & & & 6.061 & 0.755 & & & 0.069 & 0.013 & 6.897 \\
\hline & 3 & 104733 & & & 1.481 & 0.292 & & & 0.009 & 0.003 & 1.784 \\
\hline \multirow[t]{3}{*}{ AL10C } & 1 & 99030 & & & 0.081 & 0.031 & & & & & 0.112 \\
\hline & 2 & 77653 & & & 0.078 & 0.013 & & & & & 0.091 \\
\hline & 3 & 53200 & & & 0.106 & 0.033 & & & 0.003 & & 0.143 \\
\hline \multirow[t]{3}{*}{ VG0942 } & 1 & 26860 & & & 1.220 & 0.288 & & & 0.013 & 0.005 & 1.525 \\
\hline & 2 & 14427 & & & 0.219 & & & & & & 0.219 \\
\hline & 3 & 57667 & & & 0.232 & 0.035 & & & 0.033 & & 0.300 \\
\hline \multirow[t]{3}{*}{$\mathrm{AL} 4 \mathrm{~V}$} & 1 & & & & 1.777 & 0.076 & & & 0.069 & 0.025 & 1.947 \\
\hline & 2 & & & & 2.051 & 0.217 & & & 0.172 & 0.075 & 2.516 \\
\hline & 3 & & & & 2.197 & 0.122 & & & 0.217 & 0.077 & 2.612 \\
\hline \multirow[t]{3}{*}{ Min3 } & 1 & 57000 & & & 0.564 & 0.226 & & & 0.006 & & 0.797 \\
\hline & 2 & 12880 & & & 0.864 & 0.121 & & & 0.008 & 0.004 & 0.997 \\
\hline & 3 & 110867 & & & 0.123 & 0.032 & & & 0.001 & 0.001 & 0.157 \\
\hline \multirow[t]{3}{*}{ VGO577 } & 1 & 10400 & & & 5.632 & 0.851 & & & 0.141 & 0.021 & 6.645 \\
\hline & 2 & 23733 & & & 9.639 & 0.915 & & & 0.217 & 0.102 & 10.874 \\
\hline & 3 & 98400 & & & 1.770 & 0.390 & & & 0.026 & 0.016 & 2.203 \\
\hline \multirow[t]{3}{*}{ AMP4 } & 1 & 47800 & & & 6.546 & 3.159 & & & 0.351 & 0.205 & 10.261 \\
\hline & 2 & 17093 & & & 8.731 & 0.793 & & & 0.243 & 0.044 & 9.811 \\
\hline & 3 & 38067 & & & 4.527 & 0.654 & & & 0.052 & 0.035 & 5.267 \\
\hline \multirow[t]{3}{*}{ VGO874 } & 1 & 40660 & & & 0.379 & 0.200 & & & 0.111 & 0.027 & 0.717 \\
\hline & 2 & 34293 & & & 0.252 & 0.071 & & & 0.034 & & 0.357 \\
\hline & 3 & 36333 & & & 0.216 & 0.290 & & & 0.007 & 0.005 & 0.517 \\
\hline \multirow[t]{3}{*}{ RCC3227 } & 1 & 18507 & & & 0.049 & 0.006 & 0.101 & 0.016 & & & 0.173 \\
\hline & 2 & 6200 & 0.105 & 1.893 & & & 0.017 & 0.045 & 5.513 & 1.120 & 8.695 \\
\hline & 3 & 38800 & 0.219 & 0.149 & & & 0.049 & 0.006 & 0.508 & 0.111 & 1.043 \\
\hline \multirow[t]{3}{*}{ RCC3337 } & 1 & 15507 & & & 0.007 & 0.015 & 1.054 & & & & 1.076 \\
\hline & 2 & 8853 & 0.526 & 1.157 & & & 0.014 & 0.071 & 1.292 & 0.058 & 3.118 \\
\hline & 3 & 75400 & 0.067 & 1.062 & & & 0.011 & 0.015 & 0.081 & 0.119 & 1.355 \\
\hline \multirow[t]{3}{*}{ VG0650 } & 1 & 5600 & & & 0.054 & 0.041 & 10.337 & 5.244 & & & 15.676 \\
\hline & 2 & 15787 & 0.848 & 2.314 & 0.040 & 0.054 & 6.366 & 3.077 & & & 12.698 \\
\hline & 3 & 24467 & 5.385 & 2.398 & 0.043 & 0.032 & 6.410 & 5.103 & & & 19.372 \\
\hline \multirow[t]{3}{*}{ VGO651 } & 1 & 34200 & & & 0.083 & 0.027 & 6.951 & 0.973 & & & 8.034 \\
\hline & 2 & 53920 & 4.123 & 6.247 & 0.109 & 0.036 & 8.605 & 0.718 & & & 19.838 \\
\hline & 3 & 50000 & 5.406 & 7.783 & 0.138 & 0.046 & 10.735 & 1.338 & & & 25.446 \\
\hline
\end{tabular}

et al., 2011b; Stüken et al., 2011). If sxtA4 CPN and cell toxin content were also related across species, then the $A$. catenella strains should contain much more toxin compared to the A. minutum cells. Apparently, this is not the case; the toxin content per cell reported for three A. catenella strains analyzed (Murray et al., 2011b) was comparable or even less than the PST content measured for A. minutum here. An alternative explanation for the substantial difference in $s x t A 4$ CPNs observed in the two species may be linked to their genome sizes. A. catenella genomes have been estimated to be two-to-seven times larger than $A$. minutum genomes [64-100 pg; (Hackett et al., 2005; LaJeunesse et al., 2005; Figueroa et al., 2010)]. The reason for this size difference is not 

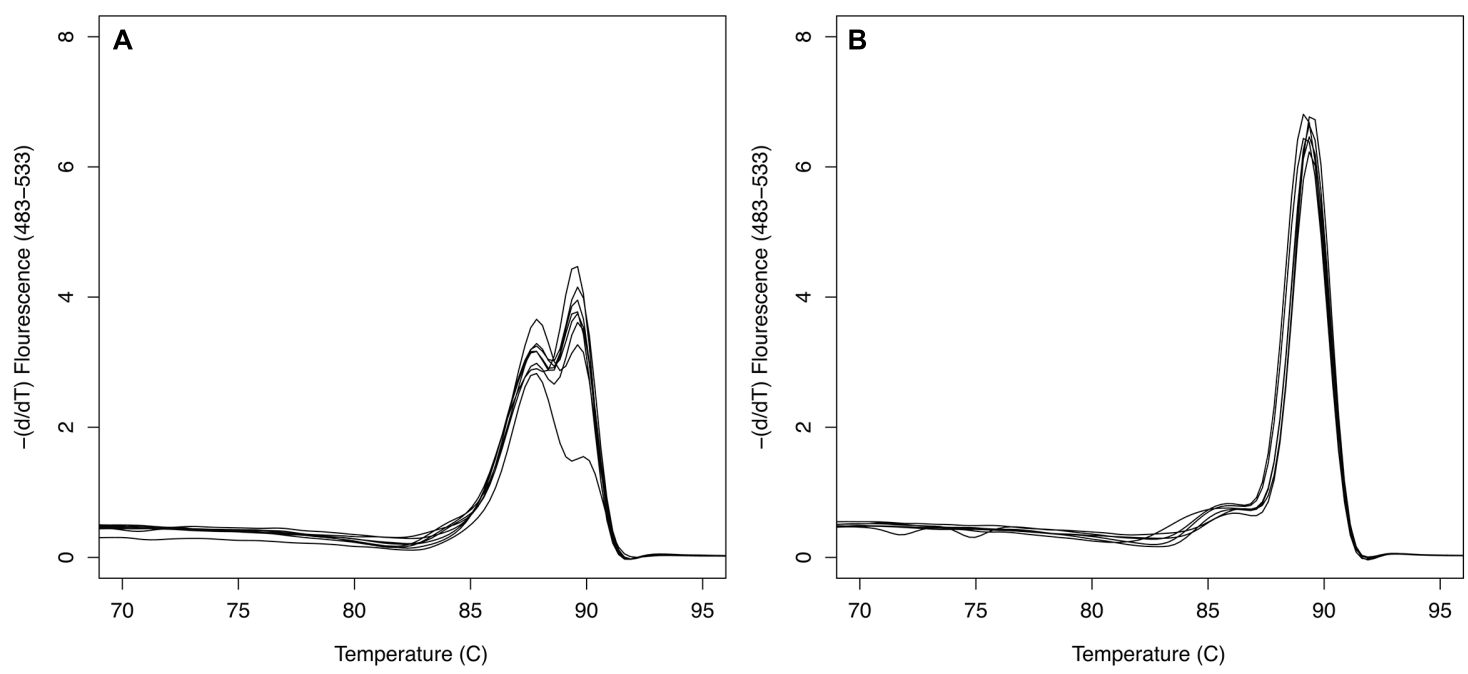

FIGURE 1 | SxtA4 qPCR melt curve comparison. (A) Bimodal melting curve of Alexandrium minutum strains VGO650, VGO651, RCC3227, and RCC3337 isolated from Brittany, France, producing PST isoforms C1/2, GTX2/3, and dcGTX2/3. (B) Single peak melting curves of strains AL1V, VGO577, AL10C, and Min3 producing PST isoforms GTX1/4 and GTX2/3.
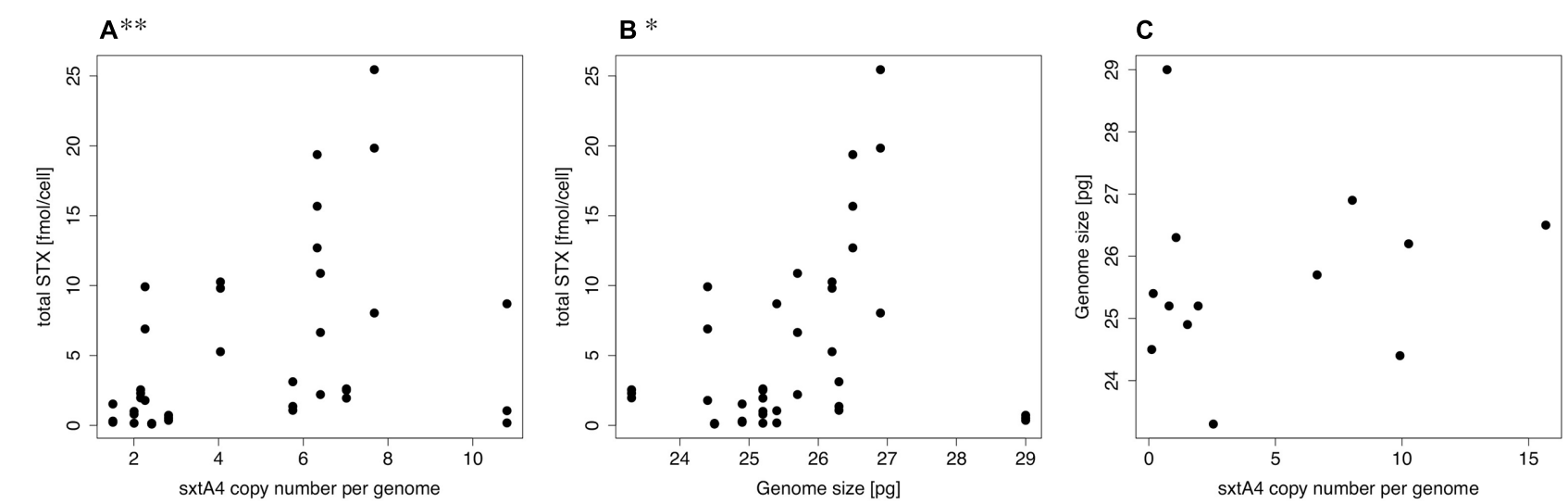

FIGURE 2 | Spearman rank order correlation plots. Scatterplots showing the relation between (A) sxtA4 copy number (CPN) per genome and total toxin content per cell, (B) total toxin content per cell and genome size, and (C) genome size and $s \times t A 4$ CPN per cell. CPN, copy number; significance level: ${ }^{* *} p \leq 0.01,{ }^{*} p \leq 0.05$.

clear, but may be related to ploidy differences. In this case, sxtA4 $\mathrm{CPN}$ would not be a positively selected trait but rather a result of genome dynamics.

However, within the species A. minutum sxtA4 CPN did not scale with genome size (Figure 2), even though we observed considerable differences in genome size (Table 1). Thus, sxtA4 CPN does not appear to be a function of genome size in A. minutum. This is the first time that so many strains of the same dinoflagellate species have been measured and that such a breath of genome size within a species has been documented. It is currently unclear what causes the genome size diversity but it might be related to chromosomal differences, as aneuploidy may be common in dinoflagellate cultures (Loper et al., 1980).

We also observed a positive correlation between genome size and toxin content (Figure 2; Table 3). It is unclear what caused this relationship, as toxin content and $s x t A 4 \mathrm{CPN}$ were positively correlated, but sxtA4 CPN and genome size were not. In dinoflagellates DNA content correlates with cell size (LaJeunesse et al., 2005; Dapena et al., 2015) a relation that has been document for most eukaryotic lineages, e.g., (Gregory, 2001; Cavalier-Smith, 2005). It is possible that cells with a higher cell volume contain more PSTs. However, studies comparing toxin content of different sized cells have, to our knowledge, not been undertaken yet.

\section{Non-PST Producing A. minutum Strain VG0663}

For one of the A. minutum strains, strain VGO663, neither PST nor $s x t A 1$, or $s x t A 4$ gene fragments were detected. While it was previously known that the species $A$. minutum contains PSTproducing and non-producing strains, e.g., (Touzet et al., 2007), this is the first $A$. minutum strain for which no $s x t$ genes could 
be amplified. The finding weakens our previous hypothesis that all strains of PST-producing Alexandrium species contain sxtA1 and sxtA4 (Stüken et al., 2011). It also adds to the growing body of evidence that the presence of $\operatorname{sxtA1}$ and $s x t A 4$ is not only a pre-requisite for PST synthesis, but is also a good indicator for its actual synthesis. A recent study of PST-producing and nonproducing $A$. ostenfeldii strains showed that all PST-producing strains contained both, $s x t A 1$ and $s x t A 4$, while either $s x t A 4$ or $s x t A 1$ and $s x t A 4$ were not detected in non-PST-producing strains (Suikkanen et al., 2013). Also, while all A. tamarense strains investigated so far contained both $s x t A 1$ and $s x t A 4$, it has been indicated that some strains classified not to produce PSTs, might indeed produce low amounts or unusual isoforms (Negri et al., 2003; Orr et al., 2011; Murray et al., 2012).

\section{Toxin Profiles and sxtA Gene Diversity}

Three groups with different toxin profiles were observed in the 15 A. minutum strains analyzed. The first group of strains isolated from different locations in the Mediterranean Sea and the Atlantic Ocean produced pre-dominantly GTX4 as well as smaller amounts of GTX1-3, the second group isolated from Brittany, France, produced mainly GTX3, but also substantial amounts of GTX2, C2, and C1, and smaller amounts of dcGTX2 and dcGTX3. The third group, strain VGO663, did not produce any measurable amounts of toxin (Table 3 ).

There was no discernable difference in total PST produced, genome size or number of sxtA4 copies per genome between $A$. minutum toxin group 1 and 2 . There was, however, a marked difference in the diversity of $s x t A$ gene copies between the two groups. This difference was clearly visible in the melt curve analyses of the sxtA qPCR amplicon: all strains of the first group had a characteristic single peak melt curve, while the strains from the second group displayed a bimodal curve (Figure 1). Detailed analyses showed that this melt curve pattern was due to the presence of three SNP sites resulting into two different $s x t A$ gene sequences in the strains from Brittany over the lengths of the qPCR amplicon. None of the other A. minutum strains contained SNPs in this region. Further, analyses of the longer sxtA4 PCR amplicon generated with primers sxt007 and sxt008 showed a much higher sequence variation in the A. minutum strains isolated from Brittany compared to the rest of the A. minutum strains analyzed. The sequence variation between these two groups seems to have developed independently - none of the SNPs coincided.

It is not clear, if the sequence variations observed are related to the PST profile produced or the site of isolation. The first scenario is unlikely because it is probably not $s x t A$ that determines which isoforms of PST are produced, but rather the presence and functioning of tailoring genes, as has been shown for cyanobacteria (Kellmann et al., 2008; Soto-Liebe et al., 2010; Murray et al., 2011a). As the entire PST pathway in dinoflagellates has not been characterized, this is currently difficult to investigate. The second scenario is more plausible. It indicates the presence of an A. minutum population at the coast of Brittany in which the sxtA genes evolve independently from the rest of $A$. minutum strains in the region. Microsatellite analyses support the presence of distinct $A$. minutum populations in the Mediterranean Sea (McCauley et al.,
2009; Casabianca et al., 2012). If this is true, then it implies that sxtA evolves not only in different species as has been suggested earlier (Stüken et al., 2011) but also in different entities within a species. In this context it is also interesting to note that the high sequence variation was only observed in domain sxtA4, not in sxtA1. It is possible that these two domains are under different selection pressures. This has already been indicated by the finding that only $\operatorname{sxt} A 1$ could be amplified in some A. ostenfeldii strains (Suikkanen et al., 2013). Further, it might give an explanation why it was so far not possible to amplify the entire $s x t A$ gene from dinoflagellate gDNA - the two domains may be encoded in different regions of the genome and are spliced together with domains sxtA2 and sxtA3 to form entire $s x t A$ transcripts.

\section{Conclusion and Future Perspectives}

The cellular regulation of PST-synthesis in dinoflagellates remains complex. Here, we have observed a strong positive relation between genomic sxtA4 CPN and PST content in actively growing $A$. minutum cells. This indicates that the number of sxt gene copies per genome may determine the amount of STX that is produced by dinoflagellate cells. It is not clear, however, if the CPN determines the maximum amount of toxin that can be produced, or if it is just an indicator for the amount of toxin that is produced under unconstraint growth conditions. For example, it has been shown that growth rate and PST synthesis in Alexandrium species are related during logarithmic growth, but that this association weakens as nutrients are depleted and the cells enter stationary phase (Boczar et al., 1988; Anderson et al., 1990; Parkhill and Cembella, 1999). Depending on the nutrient limitation, either more or less toxin is produced per cell (Anderson et al., 1990). Thus, it would be informative to investigate if strains with more CPNs per genome generally produce more toxins during unconstraint growth than those with less CPNs. Indeed, preliminary results of this group indicate that $A$. minutum cells with a higher sxtA4 CPN per genome have a higher toxin content during exponential growth phase than those with less CPNs, and that this relation lessens as nutrients are depleted and cell growth slows down. However, further experiments are needed to verify such a conclusion. In addition, it would be insightful to test if strains with more CPNs have a higher phenotypic plasticity regarding toxin production, i.e., if their response to extreme conditions shows a higher variation in toxin production than strains with fewer CPNs. Nevertheless, it is so far still unclear if genomic sxt gene $\mathrm{CPN}$ is indeed the bottleneck in PST synthesis. To investigate this, parallel analyses including toxin synthesis, genomic $\mathrm{CPNs}$, and transcript abundance of a range of strains are needed. Wiese et al. (2014) have recently published a sxtA4 qPCR assay that includes normalization targets and will facilitate such an analysis.

Our results also show that $s x t A$ sequence variability differs between $A$. minutum strains. For $A$. catenella it has recently been shown that preferential transcription of certain gene copies and mRNA editing may play important roles in the maturation of sxtA transcripts (Wiese et al., 2014). It will be interesting to 
investigate, if the same is also true for A. minutum and if this may have an impact on the total amount of toxin produced.

Finally it remains to be established if the same mechanisms regulate PST-synthesis in all Alexandrium species. Recent analyses of the ribosomal DNA in various Alexandrium species revealed distinct chromosomal organization (Figueroa et al., 2014).

\section{References}

Allen, J., Roberts, T., Loeblich, A., and Klotz, L. (1975). Characterization of DNA from dinoflagellate Crypthecodinium cohnii and implications for nuclear organization. Cell 6, 161-169. doi: 10.1016/0092-8674(75)90006-9

Anderson, D. M., Alpermann, T. J., Cembella, A. D., Collos, Y., Masseret, E., and Montresor, M. (2012). The globally distributed genus Alexandrium: multifaceted roles in marine ecosystems and impacts on human health. Harmful Algae 14, 10-35. doi: 10.1016/j.hal.2011.10.012

Anderson, D. M., Kulis, D. M., Sullivan, J. J., Hall, S., and Lee, C. (1990). Dynamics and physiology of saxitoxin production by the dinoflagellates Alexandrium spp. Mar. Biol. 104, 511-524. doi: 10.1007/BF01314358

Bachvaroff, T. R., and Place, A. R. (2008). From stop to start: tandem gene arrangement, copy number and trans-splicing sites in the dinoflagellate Amphidinium carterae. PLoS ONE 3:e2929. doi: 10.1371/journal.pone.0002929

Bergkvist, J., Selander, E., and Pavia, H. (2008). Induction of toxin production in dinoflagellates: the grazer makes a difference. Oecologia 156, 147-154. doi: 10.1007/s00442-008-0981-6

Bertomeu, T., and Morse, D. (2004). Isolation of a dinoflagellate mitotic cyclin by functional complementation in yeast. Biochem. Biophys. Res. Commun. 323, 1172-1183. doi: 10.1016/j.bbrc.2004.09.008

Boczar, B. A., Beitler, M. K., Liston, J., Sullivan, J. J., and Cattolico, R. A. (1988). Paralytic shellfish toxins in Protogonyaulax tamarensis and Protogonyaulax catenella in axenic Culture. Plant Physiol. 88, 1285-1290. doi: 10.1104/pp.88.4.1285

Casabianca, S., Penna, A., Pecchioli, E., Jordi, A., Basterretxea, G., and Cristiano, V. (2012). Population genetic structure and connectivity of the harmful dinoflagellate Alexandrium minutum in the Mediterranean Sea. Proc. Biol. Sci. 279, 129-138. doi: 10.1098/rspb.2011.0708

Cavalier-Smith, T. (2005). Economy, speed and size matter: evolutionary forces driving nuclear genome miniaturization and expansion. Ann. Bot. 95, 147-175. doi: 10.1093/aob/mci010

Dapena, C., Bravo, I., Cuadrado, A., and Figueroa, R. I. (2015). Nuclear and cell morphological changes during the cell cycle and growth of the toxic dinoflagellate Alexandrium minutum. Protist 166, 146-160. doi: 10.1016/j.protis.2015.01.001

Davies, W., Jakobsen, K. S., and Nordby, Ø. (1988). Characterization of DNA from the dinoflagellate Woloszynskia bostoniensis. J. Protozool. 35, 418-422. doi: 10.1111/j.1550-7408.1988.tb04120.x

Figueroa, R. I., Cuadrado, A., Stüken, A., Rodríguez, F., and Fraga, S. (2014). Ribosomal DNA organization patterns within the dinoflagellate genus Alexandrium as revealed by FISH: life cycle and evolutionary implications. Protist 165, 343-363. doi: 10.1016/j.protis.2014.04.001

Figueroa, R. I., Garces, E., and Bravo, I. (2010). The use of flow cytometry for species identification and life-cycle studies in dinoflagellates. Deep Sea Res. Part II Top. Stud. Oceanogr. 57, 301-307. doi: 10.1016/J.Dsr2.2009.09.008

Flynn, K., Franco, J. M., Fernandez, P., Reguera, B., Zapata, M., Wood, G., et al. (1994). Changes in toxin content, biomass and pigments of the dinoflagellate Alexandrium minutum during nitrogen refeeding and growth into nitrogen or phosphorus stress. Mar. Ecol. Prog. Ser. 111, 99-109. doi: 10.3354/meps 111099

Galluzzi, L., Penna, A., Bertozzini, E., Vila, M., Garces, E., and Magnani, M. (2004). Development of a real-time PCR assay for rapid detection and quantification of Alexandrium minutum (a dinoflagellate). Appl. Environ. Microbiol. 70, 1199-1206. doi: 10.1128/Aem.70.2.1199-1206.2004

Gregory, R. T. (2001). Coincidence, coevolution, or causation? DNA content, cellsize, and the C-value enigma. Biol. Rev. 76, 65-101. doi: 10.1111/j.1469185X.2000.tb00059.x

\section{Acknowledgments}

The work was funded by a grant from Formas (Sweden) to RIF (Formas 215-2010-824) and the Norwegian Research Council grant $186292 / \mathrm{V} 40$ to KSJ. LG received funding through the PARALEX project by the French research agency's (ANR) 2009 and GDR Phycotox (http://www.phycotox.fr).

Guillard, R. R. L., and Hargraves, P. E. (1993). Stichochrysis immobilis is a diatom, not a chrysophyte. Phycologia 32, 234-236. doi: 10.2216/i0031-8884-32-3-234.1

Guiry, M. D., and Guiry, G. M. (2013). AlgaeBase. World-Wide Electronic Publication. National University of Ireland, Galway. Available at: http://www. algaebase.org [accessed May 20, 2013].

Hackett, J. D., Scheetz, T. E., Yoon, H. S., Soares, M. B., Bonaldo, M. F., Casavant, T. L., et al. (2005). Insights into a dinoflagellate genome through expressed sequence tag analysis. BMC Genomics 6:80. doi: 10.1186/1471-2164-6-80

Hackett, J. D., Wisecaver, J. H., Brosnahan, M. L., Kulis, D. M., Anderson, D. M., Bhattacharya, D., et al. (2013). Evolution of saxitoxin synthesis in cyanobacteria and dinoflagellates. Mol. Biol. Evol. 30, 70-78. doi: 10.1093/molbev/mss142

Hou, Y., and Lin, S. (2009). Distinct gene number-genome size relationships for eukaryotes and non-Eukaryotes: gene content estimation for dinoflagellate genomes. PLoS ONE 4:e6978. doi: 10.1371/journal.pone.0006978

Jaeckisch, N., Yang, I., Wohlrab, S., Glöckner, G., Kroymann, J., Vogel, H., et al. (2011). Comparative genomic and transcriptomic characterization of the toxigenic marine dinoflagellate Alexandrium ostenfeldii. PLoS ONE 6:e28012. doi: 10.1371/journal.pone.0028012.t005

John, E., and Flynn, K. (2000). Growth dynamics and toxicity of Alexandrium fundyense (Dinophyceae): the effect of changing $\mathrm{N}: \mathrm{P}$ supply ratios on internal toxin and nutrient levels. Eur. J. Phycol. 35, 11-23. doi: $10.1017 /$ S0967026200002572

Kellmann, R., Mihali, T. K., Jeon, Y. J., Pickford, R., Pomati, F., and Neilan, B. A. (2008). Biosynthetic intermediate analysis and functional homology reveal a saxitoxin gene cluster in cyanobacteria. Appl. Environ. Microbiol. 74, 4044-4053. doi: 10.1128/aem.00353-08

LaJeunesse, T., Lambert, G., Andersen, R., Coffroth, M., and Galbraith, D. (2005). Symbiodinium (Pyrrhophyta) genome sizes (DNA content) are smallest among dinoflagellates. J. Phycol. 41, 880-886. doi: 10.1111/j.1529-8817.2005.00111.x

Le, Q. H., Markovic, P., Hastings, J., Jovine, R. V., and Morse, D. (1997). Structure and organization of the peridinin-chlorophyll a-binding protein gene in Gonyaulax polyedra. Mol. Gen. Genet. 225, 595-604. doi: $10.1007 / \mathrm{s} 004380050533$

Lee, D., Mittag, M., Sczekan, S., Morse, D., and Hastings, J. (1993). Molecularcloning and genomic organization of a gene for Luciferin-binding Protein from the dinoflagellate Gonyaulax polyedra. J. Biol. Chem. 268, 8842-8850.

Lee, R., Lai, H., Malik, S. B., Saldarriaga, J. F., Keeling, P. J., and Slamovits, C. H. (2014). Analysis of EST data of the marine protist Oxyrrhis marina, an emerging model for alveolate biology and evolution. BMC Genomics 15:122. doi: 10.1186/1471-2164-15-122

Li, L. M., and Hastings, J. W. (1998). The structure and organization of the luciferase gene in the photosynthetic dinoflagellate Gonyaulax polyedra. Plant Mol. Biol. 36, 275-284. doi: 10.1023/A:1005941421474

Liu, L. Y., and Hastings, J. W. (2005). Novel and rapidly diverging intergenic sequences between tandem repeats of the luciferase genes in seven dinoflagellate species. J. Phycol. 42, 96-103. doi: 10.1111/j.1529-8817.2006.00165.x

Loper, C. L., Steidinger, K. A., and Walker, L. M. (1980). A simple chromosome spread technique for unarmoured dinoflagellates and implications of polyploidy in algal cultures. Trans. Am. Microsc. Soc. 99, 343-346. doi: $10.2307 / 3226012$

Machabée, S., Wall, L., and Morse, D. (1994). Expression and genomic organization of a dinoflagellate gene family. Plant Mol. Biol. 25, 23-31. doi: 10.1007/BF00024195

McCauley, L. A. R., Erdner, D. L., Nagai, S., Richlen, M. L., and Anderson, D. M. (2009). Biogeographic analysis of the globally distributed harmful algal bloom species Alexandrium minutum (Dinophyceae) based on rRNA gene sequences and microsatellite markers. J. Phycol. 45, 454-463. doi: 10.1111/j.1529-8817.2009.00650.x 
McEwan, M., Humayun, R., Slamovits, C. H., and Keeling, P. J. (2008). Nuclear genome sequence survey of the dinoflagellate Heterocapsa triquetra. J. Eukaryot. Microbiol. 55, 530-535. doi: 10.1111/j.1550-7408.2008.00357.x

Moustafa, A., Evans, A. N., Kulis, D. M., Hackett, J. D., Erdner, D. L., Anderson, D. M., et al. (2010). Transcriptome profiling of a toxic dinoflagellate reveals a gene-rich protist and a potential impact on gene expression due to bacterial presence. PLoS ONE 5:e9688. doi: 10.1371/journal.pone.0009688

Murray, S. A., Mihali, T. K., and Neilan, B. A. (2011a). Extraordinary conservation, gene loss, and positive selection in the evolution of an ancient neurotoxin. Mol. Biol. Evol. 28, 1173-1182. doi: 10.1093/molbev/msq295

Murray, S. A., Wiese, M., Stüken, A., Brett, S., Kellmann, R., Hallegraeff, G., et al. (2011b). A quantitative molecular assay based on the gene sxtA to identify saxitoxin-producing harmful algal blooms in marine waters. Appl. Environ. Microbiol. 77, 7050-7057. doi: 10.1128/AEM.05308-11

Murray, S. A., Wiese, M., Neilan, B. A., Orr, R. J. S., De Salas, M., Brett, S., et al. (2012). A reinvestigation of saxitoxin production and sxtA in the 'nontoxic' Alexandrium tamarense Group V clade. Harmful Algae 18, 96-104. doi: 10.1016/J.Hal.2012.05.001

Negri, A., Llewellyn, L., Doyle, J., Webster, N., Frampton, D., and Blackburn, S. (2003). Paralytic shellfish toxins are restricted to few species among Australia's taxonomic diversity of cultured microalgae. J. Phycol. 39, 663-667. doi: 10.1046/j.1529-8817.2003.02131.x

Orr, R. J., Stüken, A., Murray, S. A., and Jakobsen, K. S. (2013). Evolutionary acquisition and loss of saxitoxin biosynthesis in dinoflagellates: the second “core" gene, sxtG. Appl. Environ. Microbiol. 79, 2128-2136. doi: 10.1128/AEM. 03279-12

Orr, R. J. S., Stüken, A., Rundberget, T., Eikrem, W., and Jakobsen, K. S. (2011). Improved phylogenetic resolution of toxic and non-toxic Alexandrium strains using a concatenated rDNA approach. Harmful Algae 10, 676-688. doi: 10.1016/J.Hal.2011.05.003

Parkhill, J., and Cembella, A. (1999). Effects of salinity, light and inorganic nitrogen on growth and toxigenicity of the marine dinoflagellate Alexandrium tamarense from northeastern Canada. J. Plankton Res. 21, 939-955. doi: 10.1093/plankt/21.5.939

Rourke, W. A., Murphy, C. J., Pitcher, G., Van De Riet, J. M., Burns, B. G., Thomas, K. M., et al. (2008). Rapid postcolumn methodology for determination of paralytic shellfish toxins in shellfish tissue. J. AOAC Int. 91, 589-597.

Ruijter, J. M., Ramakers, C., Hoogaars, W. M., Karlen, Y., Bakker, O., van den Hoff, M. J., et al. (2009). Amplification efficiency: linking baseline and bias in the analysis of quantitative PCR data. Nucleic Acids Res. 37:e45. doi: 10.1093/nar/gkp045

Sako, Y., Kim, C., and Ishida, Y. (1992). Mendelian inheritance of Paralytic Shellfish Poisoning Toxin in the marine dinoflagellate Alexandrium catenella. Biosci. Biotechnol. Biochem. 56, 692-694. doi: 10.1271/bbb.56.692

Salois, P., and Morse, D. (1997). Characterization and molecular phylogeny of a protein kinase cDNA from the dinoflagellate Gonyaulax (Dinophyceae). J. Phycol. 33, 1063-1072. doi: 10.1111/j.0022-3646.1997.01063.x

Shoguchi, E., Shinzato, C., Kawashima, T., Gyoja, F., Mungpakdee, S., Koyanagi, R., et al. (2013). Draft assembly of the Symbiodinium minutum nuclear genome reveals dinoflagellate gene structure. Curr. Biol. 23, 1399-1408. doi: 10.1016/j.cub.2013.05.062

Sommer, H., Whedon, W. F., Kofoid, C. A., and Stohler, R. (1937). Relation of paralytic shellfish poison to certain plankton organisms of the genus Gonyaulax. Arch. Pathol. 24, 537-559.
Soto-Liebe, K., Murillo, A. A., Krock, B., Stucken, K., Fuentes-Valdes, J. J., Trefault, N., et al. (2010). Reassessment of the toxin profile of Cylindrospermopsis raciborskii $\mathrm{T} 3$ and function of putative sulfotransferases in synthesis of sulfated and sulfonated PSP toxins. Toxicon 56, 1350-1361. doi: 10.1016/J.Toxicon.2010.07.022

Stüken, A., Dittami, S. M., Eikrem, W., Mcnamee, S., Campbell, K., Jakobsen, K. S., et al. (2013). Novel hydrolysis-probe based qPCR assay to detect saxitoxin transcripts of dinoflagellates in environmental samples. Harmful Algae 28, 108-117. doi: 10.1016/J.Hal.2013.06.003

Stüken, A., Orr, R. J., Kellmann, R., Murray, S. A., Neilan, B. A., and Jakobsen, K. S. (2011). Discovery of nuclear-encoded genes for the neurotoxin saxitoxin in dinoflagellates. PLOS ONE 6:e20096. doi: 10.1371/journal.pone. 0020096

Suikkanen, S., Kremp, A., Hautala, H., and Krock, B. (2013). Paralytic shellfish toxins or spirolides? The role of environmental and genetic factors in toxin production of the Alexandrium ostenfeldii complex. Harmful Algae 26, 52-59. doi: 10.1016/j.hal.2013.04.001

Taroncher-Oldenburg, G., Kulis, D. M., and Anderson, D. M. (1997). Toxin variability during the cell cycle of the dinoflagellate Alexandrium fundyense. Limnol. Oceanogr. 42, 1178-1188. doi: 10.4319/lo.1997.42.5_part_2.1178

Touzet, N., Franco, J. M., and Raine, R. (2007). Characterization of nontoxic and toxin-producing strains of Alexandrium minutum (Dinophyceae) in Irish coastal waters. Appl. Environ. Microbiol. 73, 3333-3342. doi: 10.1128/Aem.02161-06

Veldhuis, M., Cucci, T., and Sieracki, M. (1997). Cellular DNA content of marine phytoplankton using two new fluorochromes: taxonomic and ecological implications. J. Phycol. 33, 527-541. doi: 10.1111/j.0022-3646.1997.00527.x

Wiese, M., D’Agostino, P. M., Mihali, T. K., Moffitt, M. C., and Neilan, B. A. (2010). Neurotoxic alkaloids: saxitoxin and its analogs. Mar. Drugs 8, 2185-2211. doi: 10.3390/Md8072185

Wiese, M., Murray, S. A., Alvin, A., and Neilan, B. A. (2014). Gene expression and molecular evolution of sxtA4 in a saxitoxin producing dinoflagellate Alexandrium catenella. Toxicon 92, 102-112. doi: 10.1016/j.toxicon.2014.09.015

Yang, I., John, U., Beszteri, S., Glöckner, G., Krock, B., Goesmann, A., et al. (2010). Comparative gene expression in toxic versus non-toxic strains of the marine dinoflagellate Alexandrium minutum. BMC Genomics 11:248. doi: 10.1186/1471-2164-11-248

Yang, I., Selander, E., Pavia, H., and John, U. (2011). Grazer-induced toxin formation in dinoflagellates: a transcriptomic model study. Eur. J. Phycol. 46, 66-73. doi: 10.1080/09670262.2011.552194

Zhao, S., and Russell, D. F. (2005). Comprehensive algorithm for quantitative real-time polymerase chain reaction. J. Comput. Biol. 12, 1047-1064. doi: $10.1089 / \mathrm{cmb} .2005 .12 .1047$

Conflict of Interest Statement: The authors declare that the research was conducted in the absence of any commercial or financial relationships that could be construed as a potential conflict of interest.

Copyright (c) 2015 Stüken, Riobó, Franco, Jakobsen, Guillou and Figueroa. This is an open-access article distributed under the terms of the Creative Commons Attribution License (CC BY). The use, distribution or reproduction in other forums is permitted, provided the original author(s) or licensor are credited and that the original publication in this journal is cited, in accordance with accepted academic practice. No use, distribution or reproduction is permitted which does not comply with these terms. 